\title{
SIMBOL BAHASA RUPA PADA DINDING DALAM OMO SEBUA DI BAWOMATALUO NIAS SELATAN
}

\author{
Ariesa Pandanwangi, Krismanto Kusbiantoro \\ (Email: ariesa.pandanwangi@gmail.com) \\ Program Studi Seni Murni \\ Fakultas Seni Rupa dan Desain \\ Universitas Kristen Maranatha \\ Jl. Surya Sumantri No 65 Bandung, Indonesia.
}

\begin{abstract}
ABSTRAK
Berdasarkan pembagian geografisnya Nias terbagi menjadi 4 wilayah yaitu Nias Utara, Nias Selatan, Nias Timur, dan Nias Barat. Area fokus penelitian ini adalah rumah tradisional di Nias Selatan, salah satunya adalah Omo Sebua (rumah bangsawan) di desa Bawomataluo. Objek penelitian ini dipilih karena rumah tradisional Omo Sebua kaya akan simbol ragam hias tradisional khas Nias pada bagian-bagian rumahnya. Tujuan penelitian ini adalah mengetahui arti simbol pada bagian dinding dalam Omo Sebua. Metode penelitian ini menggunakan metode deksriptif kualitatif dengan pendekatan bahasa rupa untuk membaca simbol tersebut. Hasil dari penelitian ini mengungkapkan bahwa keistimewaan bahasa rupa pada Omo Sebua menceritakan status sosial dan kehidupan sehari-hari masyarakat Nias yaitu simbol bangsawan. Simbol tersebut diinspirasi dari kejadian penting pada saat itu.Simbol tersebut juga menyiratkan agar siapapun yang bertamu harus tunduk kepada pemilik rumah.
\end{abstract}

Kata kunci: bahasa rupa; Nias; Omo Sebua; simbol

\section{ABSTRACT}

Based on the geographical distribution of Nias, it is divided into 4 regions: North Nias, South Nias, East Nias, and West Nias. The focus areas of this research are traditional houses in South Nias, one of which is Omo Sebua (a noble house) in Bawomataluo village. The object of this study was chosen because the traditional house Omo Sebua is rich in traditional Nias decorative symbols on the parts of his house.The purpose of this research is to know the meaning of the symbol on the inside wall of Omo Sebua. This research using qualitative descriptive method with the approach of Visual language to read the symbol. The result of this research reveals that the special Visual language of Omo Sebua tells about the social status and daily life of the Nias people, namely the noble symbol. The symbol is inspired from important events at that time. The symbol also implies that anyone who visits should bow to homeowners.

Keywords: Nias; Omo Sebua; symbols; visual Language 


\section{PENDAHULUAN}

Bawomataluo terletak di Nias selatan, sebuah daerah yang rawan terhadap bencana alam khususnya gempa bumi, dihuni sekitar + 350.000 orang penduduk. Awal mula penduduk Nias membangun rumah tradisional yang menjadi tempat tinggalnya karena diawali untuk melindungi diri dari cuaca, menghindari dari serangan binatang babi hutan, menghindari dari incaran orang yang punya maksud tak baik, juga untuk melindungi diri dari serangan gempa bumi. Ini terbukti pada pada tahun 2005 gempa bumi dengan skala 8.5 richter meluluhlantakkan Nias. Bangunan banyak yang hancur termasuk infrastruktur untuk publik seperti jalan, jembatan, juga toko, rumah sakit, gereja, pasar bahkan rumah tradisional sebagian juga sebagian kecil terkena dampaknya. Padahal rumah tradisional ini dikenal tahan gempa karena sistem konstruksinya yang tanpa menggunakan paku juga sistem pondasinya yang bertumpu pada kayu dan tidak menggunakan semen, sehingga apabila terjadi guncangan, kayu yang bertumpu pada batu akan luwes mengikuti gerakan-gempa tersebut. Menurut bapak Ariston, Bawomataluo dihuni oleh dua atau tiga Siulu (tokoh masyarakat/bangsawan) dan di bawah Siulu terdapat masing-masing 10 Siala (kelompok masyarakat, dan masayarakat bawah). Hubungan kekerabatan mereka sangat kuat bahkan melebihi hubungan kekeluargaan. Hal ini memiliki tujuan, yaitu: 1) Sebagai upaya untuk menjaga status sosial, mereka menetapkan sistem perkawinan berdasarkan kekerabatan, 2) Setiap ada peristiwa penting melibatkan mereka semua, misalnya seperti hari kelahiran, pernikahan dan hari kematian, mereka memutuskan untuk membangun rumah. 3) Di luar norma masyarakat misalnya terjadi pelanggaran berat juga diputuskan melalui pertemuan yang keputusannya menjadi mufakat bersama. Pelanggaran yang dianggap ringan dikenai hukuman berupa denda, namun apabila pelanggaran dianggap berat maka akan diberikan hukuman yang sangat berat. Upaya lain untuk memelihara kekerabatan ini dengan melakukan pertemuan reguler yang waktunya disepakati bersama dan biasanya mereka akan mengutamakan untuk hadir dalam pertemuan yang akan membahas isu-isu sosial yang mereka hadapi bersama. Pertemuan ini disebut dengan Orahua yang dihadiri oleh perwakilan dari kelompok mereka, setiap isu yang dibahas akan didiskusikan dan diketahui oleh Siulu dan Siala. Data ini didapat dari hasil wawancara tim peneliti di Bawomataluo pada 16-05-2017.

Penduduk Bawomataluo tinggal di daerah dekat pantai, dan tinggal di rumah panggung dengan material dari kayu dengan dan hampir seluruh lingkungannya dipenuhi dengan 
monumen megalitikum yang terdapat pada jajaran depan rumah mereka. Dalam kehidupan sehari-harinya mereka menjalankan kehidupan yang sama dengan penduduk di kota-kota besar seperti mencuci baju dan mereka juga mendapatkan air bersih yang baik dan dikucurkan dengan sistem keran air yang lancar mengalir. Mereka juga menghadiri peristiwa penting dalam kehidupan mereka seperti pernikahan antar kerabat.

Struktur hunian Omo Hada terdiri atas bagian bawah berupa kolong rumah tinggal yang berisi konstruksi kayu penyangga rumah tinggal terbuat dari batang-batang pohon besar dengan usia tertentu yang ketika ditebang membutuhkan upacara adat, kemudian pada bagian tengah merupakan tempat tinggal keluarga, yang memiliki satu atau dua buah kamar yang terletak di bagian belakang, sedangkan pada bagian ruangan depan terdapat jendela dengan kayu-kayu yang mengarah ke arah horisontal yang fungsinya untuk melihsat tamu yang datang atau melihat ke jalan sekaligus berfungsi sebagai ventilasi udara, sedangkan pada bagian atapnya berupa atap pelana yang terdiri atas beberapa tahap sehingga atmosfir ruang terasa dingin apabila siang hari. Hal ini juga disebabkan karena atap penutup rumah berupa rumbia. Beberapa rumah mayoritas sudah berganti dengan material seng. Rumah penduduk di Bawomataluo, berjejer rapi ke samping, tidak ada susunan seperti sebuah kompleks di perkotaan ada tetangga depan dan tetangga belakang. Mereka hanya memiliki tetangga kearah samping kiri, tetangga ke arah samping kanan dan tetangga ke arah seberang jalan depan rumahnya. Salah satu Omo yang menjadi fokus dalam penelitian ini adalah Omo Sebua dibangun di tengah-tengah Desa Bawomataluo, rumah ini milik seorang bangsawan yang dihormati pada masanya.

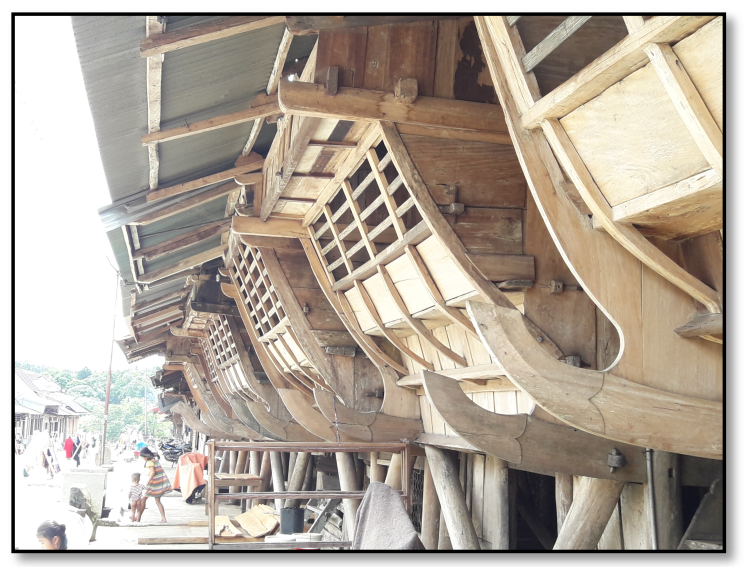

Gambar 1 Rumah Tradisional yang berderet ke arah kiri dan kanan horisontal di Bawomataluo. Sumber: Dokumentasi tim peneliti 2017. 


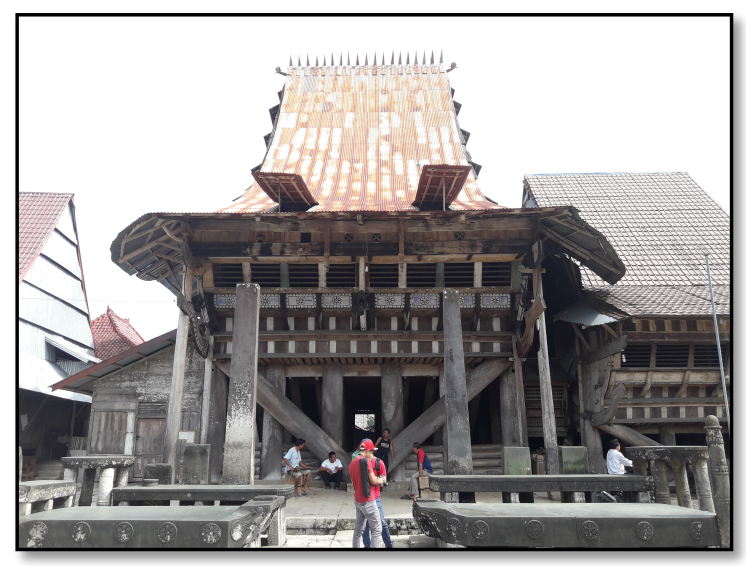

Gambar 2 Tampak depan Omo Sebua di Bawomataluo, dengan dua bukaan pada atap berfungsi sebagai sirkulasi udara, sekaligus untuk cahaya masuk kedalam Omo. Sumber: Dokumentasi tim peneliti 2017.

\section{METODE PENELITIAN}

Penelitian ini menggunakan metode deskriptif kualitatif dengan pendekatan bahasa rupa. Teknik pengambilan data dengan menggunakan studi lapangan yang didukung dengan studi literatur. Studi lapangan berupa pengambilan data wawancara dengan tokoh masyarakat setempat seperti dengan kepala desa, tokoh adat, dan juga Pastor Johannes, pendiri Museum Nias dan juga penulis buku-buku tentang Nias yang hidupnya diperuntukkan bagi masyarakat Nias dengan dedikasinya yang luar biasa bagi pelestarian budaya Nias.

Sebelum membahas hasil penelitian ini, maka ada beberapa istilah yang perlu kita pahami terkait dengan penelitian ini, yaitu istilah Omo (rumah) yang berasal dari kata Owo (perahu). Kata ini telah mengalami gejala perubahan dari kata Owo-Gomo-Omo. Pada awalnya ada perahu datang dari pulau seberang yang mengarungi lautan luas, kemudian berlabuh di Susua-gomo. Kebiasaan hidup Masyarakat Nias yang selalu dikelilingi air dari negeri asalnya dan dari kehidupan dalam perahu di atas gelombang laut, maka muncul inspirasi untuk menciptakan dan mengembangkan hunian 'rumah' di darat. Ternyata setelah mendirikan hunian di darat, goncangan gelombang tidak berhenti tetapi hampir selalu datang. Pulau Nias kerap gempa bumi, sehingga nama pulau ini dulunya disebut 'hulosolaya:laya' bukan pulau Nias yang dikenal sekarang. Usaha yang dilakukan oleh masyarakat Nias agar bisa bertahan hidup, maka tempat tinggal disesuaikan dengan kondisi alam yang baru, yaitu hunian harus dapat bertahan di pulau yang bergoyang ibarat sebuah perahu yang terkena hempasan ombak namun kapal tetap dapat berlayar (Duha, 2012:5-6). 
Arti kata Sebua secara harafiah adalah Kepala Desa ada juga yang mengatakan bangsawan. Jadi Omo Sebua adalah sebuah rumah besar yang ditinggali oleh seorang kepala desa atau bangsawan bersama dengan keluarganya. Pada bagian depan Omo Sebua terdapat menhir yang berasal dari peninggalan zaman megalitikum, yaitu batu besar yang letaknya berjejer dihalaman depan Omo Sebua.

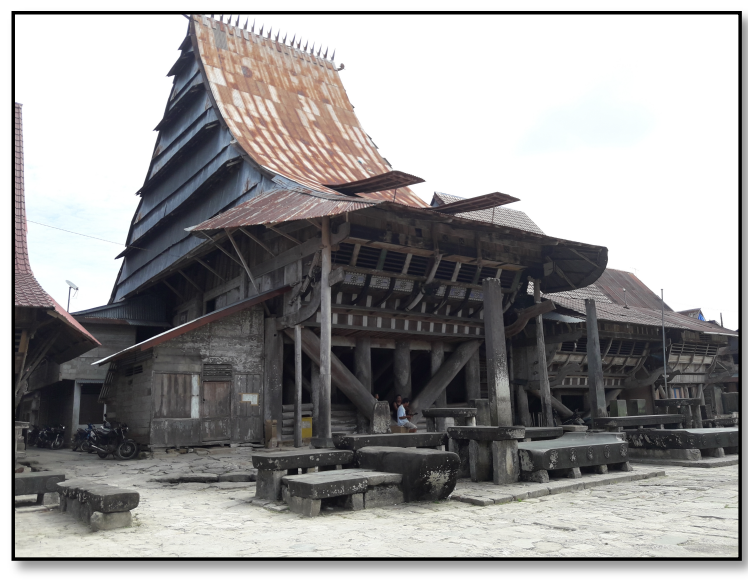

Gambar 3. Omo Sebua

Sumber: Dokumentasi Tim Peneliti 2017.

Bahasa rupa pada Omo Sebua terdapat pada dinding dengan material dari kayu yang terdapat pada dinding sebelah kiri dan kanan, dan di tengah-tengah ruangan berfungsi sebagai ruang multi fungsi yaitu tempat berkumpul keluarga dan juga berfungsi tempat upacara adat dalam keluarga ataupun untuk menerima tamu dari luar. Bahasa rupa yang dimaksud adalah sebuah gambar yang dibuat di atas dinding kayu dengan bentuk yang ditorehkan atau diukir atau dibuat semi tiga dimensi.

Bahasa rupa pada Omo Sebua terbagi dua yaitu terletak pada: 1) di bagian dinding kiri yang terbagi menjadi dua bagian yaitu bagian atas dan bagian bawah (Gambar 4 dilihat dari arah pintu masuk). 2) di bagian dinding kanan yaitu bagian atas dan bagian bawah. Keduanya mengarah ke arah horizontal.

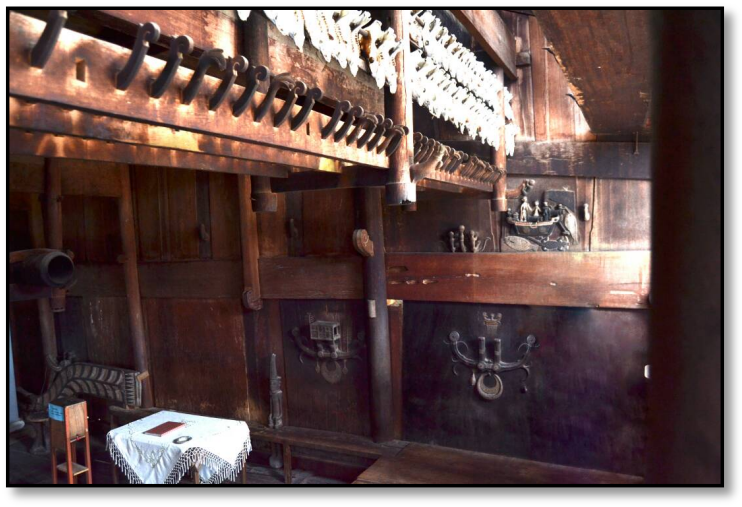




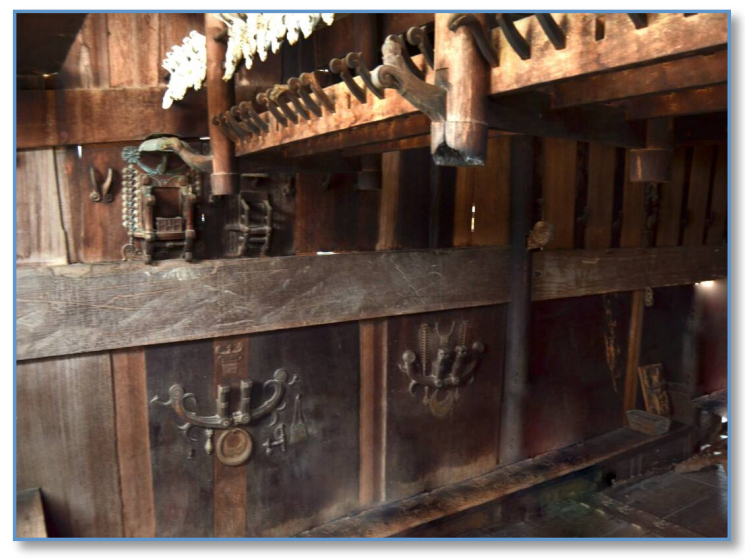

Gambar 5 Tampak bahasa rupa pada dinding dalam (kanan) Omo Sebua di Bawomataluo. Sumber: Dokumentasi Tim peneliti 2017

Bahasa rupa yang dimunculkan adalah wimba figur, flora, fauna, kapal, juga simbol-simbol status sosial. Dibuat timbul dari dinding kayu. Selain itu juga bahasa rupa yang diangkat dari peristiwa kehidupan sehari-hari seperti pengaruh lingkungan atau peristiwa penting dalam sejarah ataupun status sosial dari lingkungan itu sendiri.

\section{Bahasa Rupa}

Tabrani (dalam Vilna, 2016) mengungkapkan bahwa bahasa rupa adalah alat untuk membaca sebuah gambar yang representatif. Biasanya berupa suatu gambar atau karya visual yang bercerita yang dipakai untuk memahami gambar anak, gambar karya manusia primitif, lukisan pra-sejarah, relief candi, wayang beber, wayang kulit dan wayang golek, gambar ilustrasi, gambar periklanan, film, sinetron, dan karya seni visual bercerita lainnya.

Bahasa Rupa yang dicetuskan oleh Profesor Primadi membagi Karya visual manusia menjadi dua yaitu RWD (Ruang Waktu Datar) dan NPM (Naturalis-Perspektif-Moment Opname). Gambar anak dan gambar tradisi lebih dekat dengan gaya gambar RWD, dimana setiap objek yang 
berbeda ruang dan waktunya dapat digambarkan bersama-sama di dalam satu tema. Pada gambar RWD pula, gambar seakan bergerak dan bercerita tanpa frame.

Berbeda dengan gaya gambar NPM yang lebih dekat dengan gaya gambar dari budaya barat, dimana gambar hanya melukiskan sebuah adegan yang diam (still picture) dan ditarik dalam satu perspektif, yang didalamnya tidak ada perbesaran dan penyederhanaan gambar (Tabrani, 2005). Dalam penelitian ini bahasa rupa yang akan dipergunakan untuk membaca simbol dalam rumah adat Nias dengan menggunakan teknik sinar-X atau transparan; Bagian yang penting dibuat besar dan Aneka tampak.

\section{PEMBAHASAN}

Di bawah ini akan dipaparkan bahasa rupa yang terdapat pada Omo Sebua. Bahasa rupa yang akan dibahas terdapat pada layout rumah tinggal yang terletak di dinding kiri dan dinding kanan, sehingga mempengaruhi alur baca bahasa rupa tersebut. Bahasa rupa tersebut dapat diamati pada gambar di bawah ini

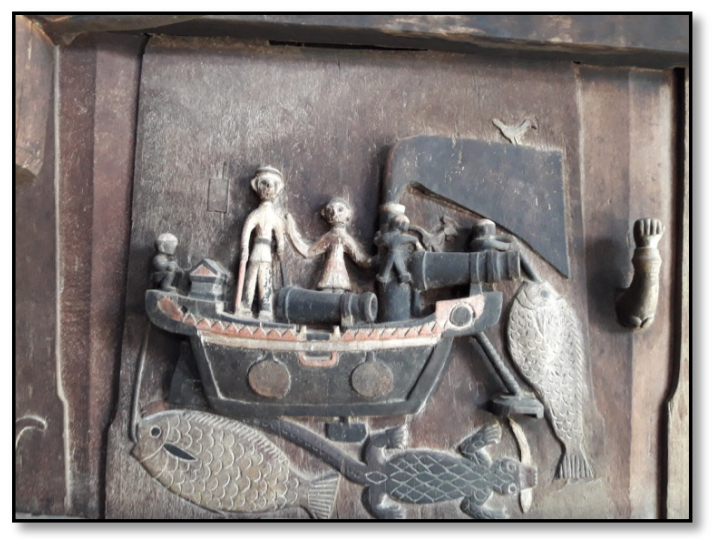

Gambar 6. Bahasa rupa pada dinding kiri dari arah pintu masuk. Sumber: Dokumentasi tim peneliti 2017

Wimba yang terdapat dalam gambar 6 adalah kapal, lima orang figur, satu buah mesin kapal di bagian belakang, 2 buah meriam, sauh kapal yang mengembang, dua buah tali pancing, dua ekor ikan besar, seekor buaya. Bahasa rupa dari ragam hias ini terletak di sebelah kanan pada dinding interior ruang depan. Bahasa rupa yang diceritakan adalah sebuah kapal Belanda yang sedang berlabuh di tengah laut, lengkap dengan perlengkapan rantai jangkar serta dua buah meriam yang siaga dan sauh yang dipergunakan untuk berlayar dilengkapi dengan semacam 
tali-temali. Kapal dinahkodai oleh seorang pelaut yang digambarkan lebih besar dari figur lainnya sehingga tampak dipentingkan dengan pakaian dan topi yang dikenakannya, sedang memberikan instruksi kepada para anak buahnya yang sedang memancing ikan besar. Ikan dianggap penting karena dibuat dalam bentuk yang besar dan mendominasi relief ini dengan teknik sinar $\mathrm{X}$ atau transparan. Di antara dua ekor ikan terdapat seekor buaya. Seorang yang tidak dianggap penting sedang jongkok di atas geladak kapal ditugaskan untuk mengendalikan mesin kapal. Sedangkan serdadu lainnya diinstruksikan untuk berjaga-jaga di depan meriam yang siaga. Tampak sauh kapal sedang dikendalikan menyesuaikan dengan arah angin.

Bahasa rupa di atas terkait dengan peristiwa dalam sejarah di Nias, berdasarkan catatan Pastor Johannes, salah satu informan dalam penelitian ini, yang juga pendiri dan penggagas berdirinya Museum Nias, memperkirakan sebuah kapal dari Belanda memasuki pelabuhan Nias Selatan. Hal inilah yang mempengaruhi gagasan dan ide dari penduduk untuk menjadikannya bagian dari ragam hias yang menghias rumah mereka. Berdasarkan runutan sejarah Belanda masuk ke Indonesia pada tahun 1668, dan pada tahun 1840 membangun pos di Gunung Sitoli. Selanjutnya tahun 1847 mendirikan pos di Lagundri, Nias Selatan, hingga pada akhirnya menguasai Nias tahun 1908. Sedangkan Omo Sebua mulai dibangun 1870.

Bahasa rupa pada bagian bawah kapal dapat diamati pada gambar di bawah ini, yaitu

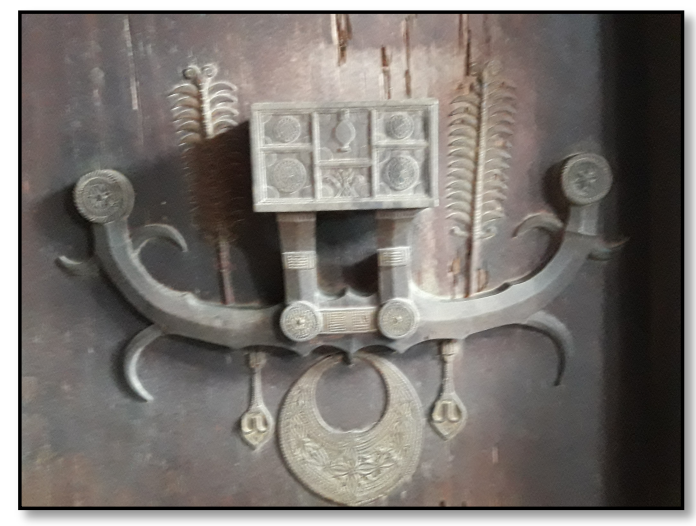

Gambar 7. Bahasa rupa dinding sebelah kiri dari arah pintu masuk. Sumber: Dokumentasi tim peneliti. 2017

Wimba pada gambar 7 adalah pada bagian atas tampak sebuah kotak yang disangga oleh dua buah penyangga. Kotak diapit oleh dua macam tumbuhan mirip dengan daun pada mahkota raja (saembu). Saembu adalah salah satu perhiasan pria. pada bagian puncaknya tampak diukir 
dengan hiasan berbentuk pucuk daun yang disebut rai. Wimba ini memiliki makna simbolik lambang kebesaran dan kemuliaan (Zebua, Baziduhu. 2005: 46). Sedangkan pada bagian tengah mirip dengan wimba tanduk rusa (waha mboho) dianggap sebagai lambang keperkasaan.

Pada bagian tengah bawah wimba yang diukir seperti nifatofato yaitu sejenis perhiasan perempuan yang digantungkan di leher. Hal ini mempunyai makna simbolik barupa lambang kebesaran. (Zebua, 2005: 47). Bahasa rupa kalung perempuan digambarkan besar dan tampak penting dan sepasang sebuah perhiasan telingan terletak disebelah kiri dan kanan kalung tersebut. Bahasa rupa yang hendak disampaikan adalah bahwa pemilik rumah tersebut seorang bangsawan terdiri atas suami dan istri yang memiliki status sosial dengan ditunjukkannya harta mereka yang dimilikinya berupa perhiasan.

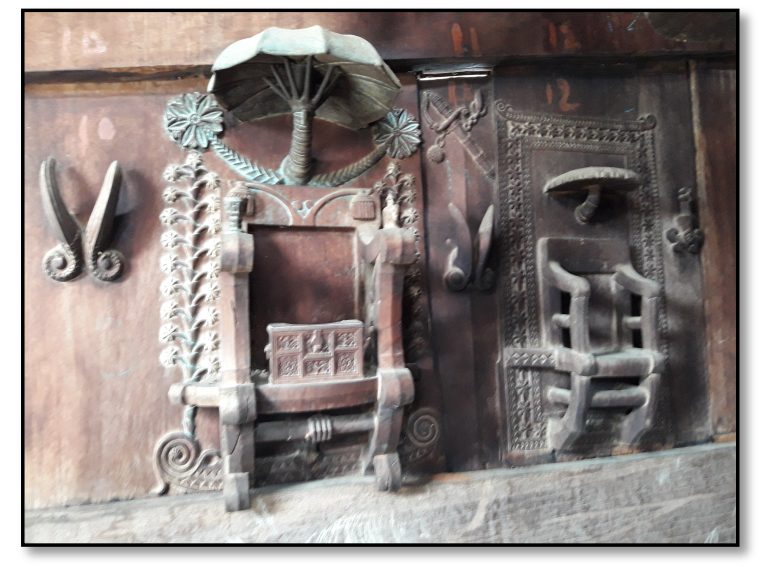

Gambar 8. Bahasa rupa Relief pada dinding sebelah kiri dari arah pintu masuk. Dokumentasi: tim peneliti 2017

Bahasa rupa selanjutnya adalah gambar 8 Wimba dalam gambar 8 tampak pada bagian atas berupa mahkota yang pada bagian bawahnya menyerupai bentuk sisir. Pada bagian tengah terdapat tiang yang menyerupai tanduk, diapit oleh dua buah tanduk dengan bentuk lingkaran pada bagian ujung tanduk dan ornamen melingkar pada bagian batang. Pada bagian bawah tampak sebuah perhiasan berupa kalung perempuan yang melingkar dan berbentuk besar, tampak dipentingkan dan diapit pada sebelah kiri oleh sebuah kalung. Bahasa rupa yang disampaikan pada ragam hias ini menceritakan status sosial bangsawan pemilik Oma Sebua dan lambang kebesaran sebagai bangsawan pada masanya. 


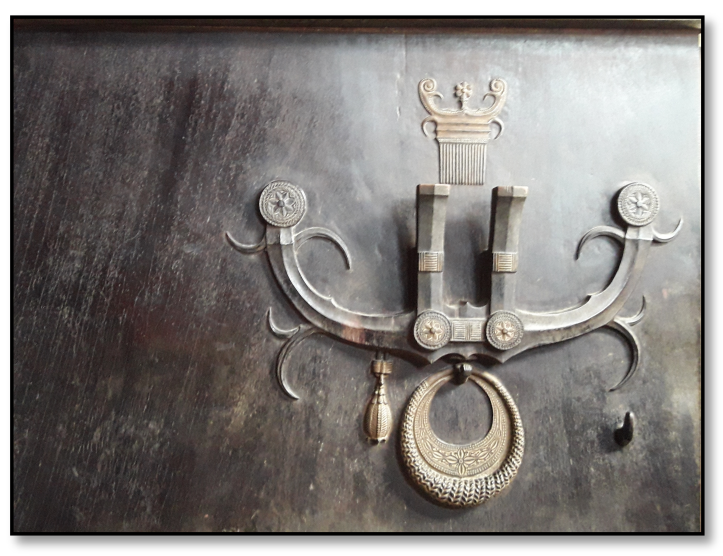

Gambar 9. Bahasa rupa pada dinding sebelah kanan dari arah pintu masuk. Sumber: Dokumentasi tim peneliti 2017

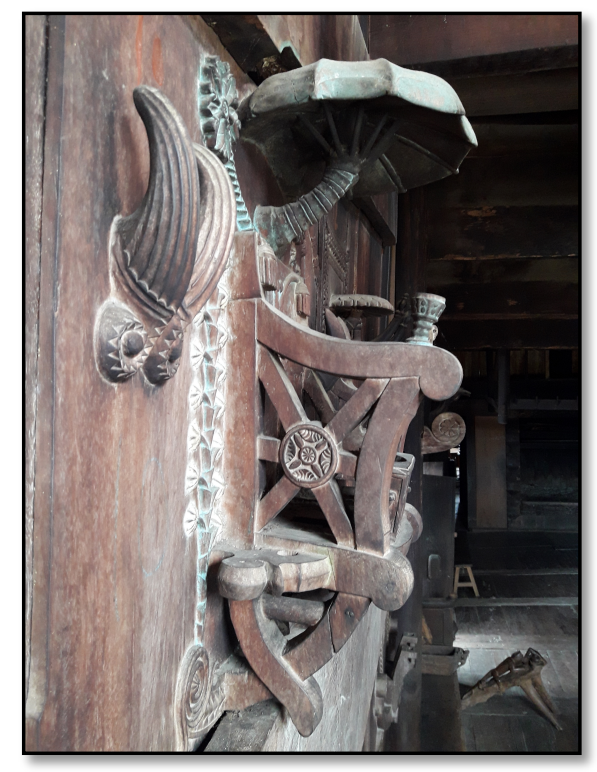

Gambar 10. Tampak samping bahasa rupa pada dinding sebelah kanan dari arah pintu masuk. Sumber: Dokumentasi tim peneliti 2017

Bahasa rupa yang disampaikan adalah kursi kebesaran bangsawan berikut dengan payung kebesarannya digambarkan tampak menonjol keluar dari dinding kayu. Kursi yang besar tampak dipentingkan dimaknakan sebagai tempat duduk bangsawan, sedangkan kursi yang lebih kecil tampaknya sebagai tempat duduk istri bangsawan. Wimba tanduk yang terletak di sebelah kiri kursi kebesaran untuk bangsawan tampaknya menegaskan sebagai simbol keperkasaan. Bahasa rupa yang disampaikan adalah bahwa pemilik rumah dari kalangan bangsawan dengan simbol kursi dan payung kebesaran. 


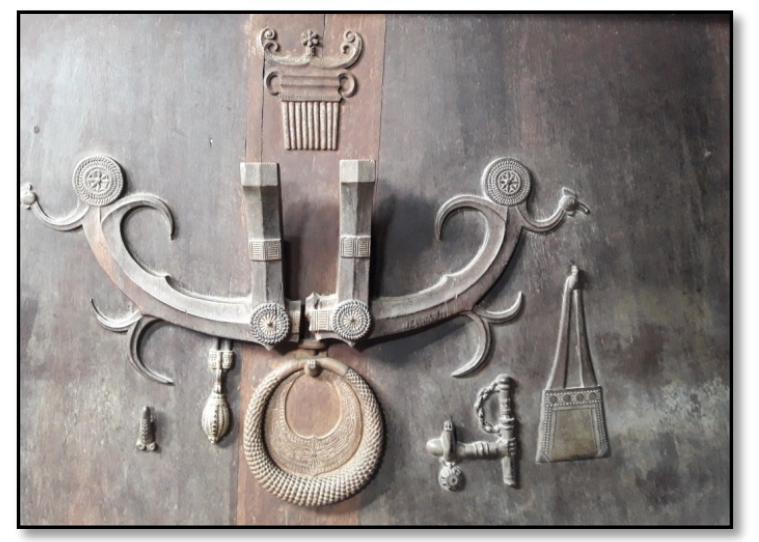

Gambar 11. Bahasa rupa dinding sebelah kanan dari arah pintu masuk, terletak pada panel dibagian bawah kursi bangsawan.

Sumber: Dokumentasi tim peneliti. 2017

Bahasa rupa pada gambar 11 terdapat pada dinding sebelah kanan dari arah pintu masuk kolong bawah. Bahasa rupa ini adalah wimba mahkota raja dengan sisir dan pada bagian bawah adalah wimba kalung yang dipakai oleh perempuan, ditumpuk dengan wimba kalung lelaki yang biasa dipakai berperang. Biasanya materialnya terbuat dari tempurung kelapa atau tanduk rusa, fungsinya untuk menangkis pedang dari serangan musuh ketika berperang. Wimba lainnya adalah perhiasan anting-anting dan tas. Anting-anting sebelah kanan, sedangkan sebelah kiri tanpa anting tetapi terdapat wimba tas, merupakan simbol kelengkapan perempuan ketika bepergian. Hal ini menunjukkan bahwa tas sebagai bagian dari status sosial bangsawan perempuan ketika meninggalkan rumah. Wimba kalung dibuat besar, dianggap penting. Sedangkan pada bagian atas kalung tampak seolah sepasang tanduk yang merupakan simbol dari keperkasaan. Tampaknya bahasa rupa ini menceritakan penghuni rumah yang berasal dari status sosial yang penting di masyarakat, digambarkan melalui simbol-simbol status sosial.

Berdasarkan paparan bahasa rupa di atas bahasa rupa yang terdapat di Omo Sebua terbagi atas wimba flora, wimba fauna, wimba campuran yang terdiri atas perhiasan, furnitur dan juga gabungan dari flora. Kejadian yang disampaikan merupakan kejadian dari peristiwa yang telah terjadi, dan status sosial dari lingkungan sehari-hari. 


\section{PENUTUP}

Bawomataluo adalah sebuah kawasan rumah tradisional yang dilestarikan oleh pemerintah setempat dan menjadi obyek penelitian dari manca negara. Keistimewaan kawasan ini adalah:

1) Rumah tradisional berjajar ke arah horisontal kiri dan kanan.

2) Rumah tradisional terbesar adalah Omo Sebua yang ditempati oleh bangsawan. Rumah tersebut hanya ada satu di kawasan ini, dan memiliki pintu masuk rumah yang berbeda, karena masuk dari kolong rumah yang berbentuk panggung. Hal ini merupakan simbol bahwa siapapun yang bertamu harus tunduk kepada pemilik rumah.

3) Sedangkan keistimewaan bahasa rupa yang terdapat di Omo Sebua menceritakan status sosial dan kehidupan sehari-hari masyarakat NiasSimbol tersebut diinspirasi dari kejadian penting pada saat itu.

4) Simbol yang ditunjukkan adalah simbol kursi kebesaran dan payung kebesaran beserta simbol-simbol lainnya seperti mahkota raja dan sisir, kalung, dan juga kotak perhiasan.

Pada akhir tulisan ini, tim peneliti mengucapkan terimakasih kepada Kemenristekdikti yang telah mendanai hibah penelitian fundamental ini. Penelitian ini merupakan penelitian awal dari proses penelitian yang masih terus berlangsung.

\section{DAFTAR PUSTAKA}

Draft Master Plan Pelestarian Bawomataluo, (2013). Kerjasama Universitas Gajah Mada-Indonesia dan Universitas Tsukuba-Japan.

Hammerle, Pastor Johannes, OFMCap. (2015). Asal-usul Masyarakat Nias: Suatu Interpretasi. Nias: Yayasan Pusaka Nias.

Duha, Nata'alui. (2012). Omo Niha: perahu darat di pulau bergoyang. Nias: Museum Pusaka Nias. Tabrani, Primadi. (2012). Bahasa rupa. Bandung: Kelir.

Zebua, Baziduhu. (2005) Rumah Adat Tradisional Nias. Nias: Museum Pusaka Nias.

Nyolinda, V.A.,\& Hartanti, M. (2016). Campaign to Introduce Children Yoga to the Mothers in Bandung City.Journal of Visual Communication Design, 1(1),18-32.

Data Wawancara lapangan dari tanggal 14-16 Mei 2017 di Kabupaten Nias. 